\author{
DOLORES BRANDIS E ISABEL DEL Río
}

Departamento de Geografía Humana. Universidad Complutense de Madrid

\title{
Paisaje y cultura en la oferta y promoción del turismo en España (1875-1936)'
}

\section{RESUMEN}

En la primera etapa del turismo español, cuyo comienzo se reconoce a partir del último tercio del siglo XIX y se cierra en la guerra civil, los productos turísticos, aunque limitados, se identifican con escenarios bien definidos relacionados con el papel que juega el paisaje natural y el patrimonio cultural en su oferta y promoción. El estudio aborda las estrategias que desarrollan los sectores público y privado diferenciando dos etapas. En la primera el protagonismo recae en intervenciones de agentes particulares circunscritas a enclaves muy localizados. En la segunda, ya a principios del siglo xx, entra en escena la Administración central, que aspira a definir la identidad turística nacional, al tiempo que iniciativas colectivas locales se esmeran en especificar sus diferencias regionales.

\section{RÉsumÉ}

Paysage et culture dans l'offre et promotion du tourisme en Espagne (1875-1936).- Dans la première étape du tourisme espagnol, dont le début est reconnu depuis le dernier tiers du XIX ${ }^{\mathrm{e}}$ siècle jusqu'à la guerre civile, les produits touristiques, bien que limités, sont identifiés avec des scénarios bien définis liés au rôle joué par l'offre et promotion du paysage naturel et patrimoine culturel. L'étude porte sur les stratégies développées par le secteur public et privé en deux étapes. Dans la première, le rôle principal est tenu par les interventions des agents particulaires confinés aux enclaves très localisées. Dans la deuxième, l'Admi-

$E^{1}$ germen de las prácticas turísticas se identifica en Europa desde mediado el siglo xviII a raíz de los cambios económicos y la renovación ideológica, científica y cultural que transforman los usos y costumbres de la sociedad.

\footnotetext{
${ }^{1}$ Este trabajo se ha realizado dentro del proyecto de investigación CSO201238425, financiado por el Ministerio de Economía y Competitividad.
}

nistration centrale entre en scène au début du $\mathrm{xx}^{\mathrm{e}}$ siècle visant à définir l'identité nationale du tourisme, pendant que les initiatives collectives locales essaient de spécifier leurs différences régionales.

\section{ABSTRACT}

Landscape and culture in the supply and promotion of tourism in Spain (1875-1936).- Certain tourism products are identified during the first stage of Spanish tourism (from the last third of the 19th century to the civil war) with well-defined scenarios related to the supply and promotion of natural landscape and cultural heritage. This paper shows the strategies of both the public and private sectors in two stages. In the first one, the stress is on the actions carried out by particular agents restricted to very specific locations. In the second one, the central administration comes into play at the beginning of the 20th century and aims to define the national tourism identity while local initiatives try to specify their regional differences.

\section{Palabras Clave/Mots Clé/Keywords}

Paisaje, patrimonio cultural, imagen e identidad, política turística, oferta y promoción turística.

Paysage, patrimoine culturel, image et identité, politique du tourisme, offre touristique et promotion touristique.

Landscape, cultural heritage, image and identity, tourism policy, tourism supply and tourism promotion.

Los primeros escenarios turísticos aparecen en Inglaterra y Centroeuropa asociados a la práctica de los baños en fuentes y manantiales de aguas con propiedades medicinales, integrados en paisajes naturales de indudable valor. En España, aunque estos hábitos se conocen desde antiguo, no se explotan como producto turístico hasta un siglo después, cuando, además, se suma la práctica del baño en agua de mar. 
A principios del siglo xx, el turismo en España adquiere una importante significación política. El Gobierno lo contempla como una oportunidad para atraer ingresos del exterior y para construir y exportar una nueva idea de España que sustituya a la maltrecha imagen política y social del país de finales del XIX. Y en paralelo surgen iniciativas locales que promocionan sus territorios con vistas al turismo. Para ello se apoyan en sus paisajes naturales y culturales y potencian los símbolos de identidad regional que descarta la administración.

Aspectos parciales que inciden en el panorama descrito, como la política turística, la oferta y promoción de los destinos o la creación y difusión de imágenes e identidades con fines turísticos, se han tratado en los últimos años por investigadores de distintos campos del conocimiento. En historia moderna y contemporánea, cabe destacar a Alonso, Arcas/García, Blasco, Cabanes/González, $\mathrm{Cal}$, Correyero/Cal, Caz/Saravia, Jerrasé, Larrinaga, Lavaur, Madrazo, Marchena, Moreno, Montaner, Pellejero, Rodrígez y Vilar; en economía a Torres; en ciencias de la información a Estévez y Martínez; en historia del arte a Martín y Ortuela; en derecho a Jaimez; en literatura a Valero; en filología a Roca; en turismo a González, Puche/ Obiol; en geografía a Domínguez, Garay/Cánoves, Gil de Arriba, Jiménez, Molina, Monserrat, Ortega y Tatjer. Todas ellas se han utilizado para articular esta investigación y han sido fuente de información de asuntos que especialmente interesan.

El trabajo parte de un doble presupuesto. En este primer periodo del turismo español la oferta de turismo se identifica con escenarios bien definidos, donde el paisaje natural y el patrimonio cultural juegan diferentes papeles que van cambiando con el tiempo, y las imágenes turísticas difundidas reflejan los intereses de los agentes que las emiten. En base a esto, el texto que sigue se centra en el análisis de la oferta y la promoción del turismo para descubrir el papel jugado por los actores implicados y, en paralelo, examina las estrategias empleadas por éstos para definir las imágenes que difunden. En el trabajo se diferencian dos etapas, con el punto de inflexión en el comienzo de la política turística a principios del siglo xx. En la primera el protagonismo recae en intervenciones de agentes particulares circunscritas a enclaves muy localizados. En la segunda, ya a principios del siglo xx, entran también en escena la Administración central, que aspira a definir la identidad turística nacional, e iniciativas colectivas locales interesadas en marcar su especificidad regional. La segunda etapa no se entiende sin la primera, pues en ella se perfilan buena parte de los escenarios de turismo que se afianzan a partir de entonces.

\section{EL PROTAGONISMO DEL SECTOR PRIVADO EN LA OFERTA Y PROMOCIÓN DE TURISMO ENTRE 1875 Y 1905}

Siguiendo la tendencia marcada por Europa, los primeros escenarios turísticos en España responden a la demanda de la práctica social del baño con fines curativos y a la consideración de negocio por parte de los promotores. Para los usuarios la toma de aguas implica salir de la ciudad, obligando al viaje, y se asocia al descanso que más tarde se traduce en veraneo. Las virtudes de las aguas minerales proclamadas desde el pensamiento higienista pronto se amplían a las aguas marinas. Cuando las propiedades terapéuticas de aquéllas pierden atractivo, los enclaves sufren la competencia del baño que proporciona el agua del mar, empleado como cura pero también para mitigar el calor estival. Con el tiempo, las mayores exigencias de entretenimiento de la demanda asidua obligan a los balnearios a introducir actividades de ocio como complemento. Los centros de aguas minerales sin capacidad para adaptarse pierden clientela y languidecen a finales del siglo XIX. Por el contrario, los baños de mar adquieren relevancia al beneficiarse de emplazamientos más asequibles y estar próximos a poblaciones con servicios y alternativas de diversión.

En esta primera etapa también se reconoce una oferta de excursiones fomentada por grupos que promueven el gusto por la naturaleza y el patrimonio entre el público local, dando a conocer lugares y territorios de singular belleza paisajística e interés cultural a través de viajes cortos y distintas formas de difusión.

\section{LA INICIATIVA PARTICULAR PROMOTORA DE LOS ENCLAVES DE BAÑOS DE AGUAS MINERALES Y DE MAR}

La dimensión curativa y el medio natural constituyen las piezas claves del atractivo de los balnearios, tanto si están localizados en el interior como en el litoral. Y promotores particulares desarrollarán estrategias para adaptarlos a los gustos de la demanda y facilitar su accesibilidad, factores clave para su desarrollo.

\section{A. El papel del paisaje natural}

Los establecimientos de aguas minerales europeos se localizan en lugares con un marco pintoresco, y está demostrado que sirvieron de cabeza de puente a los pintores románticos y a los primeros montañeros en la búsqueda de paisajes y nuevos escenarios. La ubicación de los bal- 
nearios de Europa muestra claramente su concentración en escenarios de montaña y forestales. En España, la impronta de la naturaleza se evidencia en la localización de los ciento cincuenta enclaves del Mapa balneario de España de 1867 (Madrazo, 1991), que reproduce con gran fidelidad la orografía del territorio.

Aunque el balneario de aguas minerales se organiza en torno al agua y en el agua tiene su razón de ser, la calidad ambiental y la estética del paisaje del entorno cobran un gran protagonismo. Sin duda alguna las razones son también geológicas, pero millares de fuentes no se desarrollarán por falta de un marco pintoresco. Las variantes reconocidas son muchas, desde los interiores montañosos de relieves contrastados y con exuberante vegetación, la media montaña con diversidad de paisajes vegetales, las que añaden a la riqueza natural las vistas al mar y hasta las que en el contacto con el mar encuentran su atractivo ${ }^{2}$.

$\mathrm{Si}$ en un principio los proyectos de balnearios contemplan como parte de la oferta la naturaleza del propio enclave y la de su entorno, con el tiempo el paisaje llega a domesticarse y a tomar tintes urbanos. Esta naturaleza artificializada se organiza mediante el trazado de paseos, parques, jardines, arboledas, estanques y se amansan riachuelos y lagos, adornados con terrazas y pérgolas. Todo configura un microcosmos paisajístico que pretende construir un espacio a imagen del medio urbano. En los entornos del balneario el paisaje se concibe como complemento al disfrute de la estancia mediante paseos a pie, visitas y excursiones que exhiben en el recorrido elementos singulares de la naturaleza y testimonios culturales del pasado. Cascadas, bosques, ruinas o abadías, unidos por una red de veredas y senderos, se inmortalizan en numerosas postales y litografías, cuyo análisis revela que se trata de una puesta en escena, con caminos orillados de bancos que llegan a miradores prefijados (Jerrasé, 2002). En la búsqueda de nuevos escenarios, la excursión, si la costa está cerca, puede finalizar con un baño en el mar, o, si interesan lugares más lejanos, se emplea un medio de transporte, como ofrece el balneario de la Fuente del Toro, en la sierra madrileña, para visitar el Pontón de la

\footnotetext{
${ }^{2}$ Sirva para ilustrar la gran variedad de localizaciones de algunos balnearios catalanes: La Font Pudosa gira en torno al lago de Banyoles, conjunto de características geológicas, botánicas y zoológicas de alto valor; Montagut, en el corazón de los Pirineos, está rodeado de relieves muy contrastados y diversidad de paisajes vegetales; en Termas, comarca de La Selva, la combinación de rocas, árboles y despeñaderos configuran un paisaje de singular belleza; la Puda de Monserrat está abrazada por montañas que la protegen de los vientos del norte y disfruta de la influencia del aire del mar; en Caldes d'Estrac, en el Maresme, se combinan las aguas termales con los baños de ola, y el paisaje marítimo con una montaña de bosque mediterráneo de árboles centenarios (Molina, 2004).
}

Oliva, el poblado del Vellón, los sifones del canal del Lozoya, Miraflores o la presa de Manjirón (Guía, 1897).

En los balnearios al borde del mar, la integración con la naturaleza reviste otro carácter. La finura de la arena y la calidad de las aguas son el escenario de valor para el baño y como marco son la vista del mar y la belleza del paisaje que lo circunda. Así, los atractivos naturales que dan juego en la fama nacional e internacional al balneario de San Sebastián son la calidad de las playas, la bahía, los montes Igueldo, Ulía y la isla de Santa Clara. Pero la naturaleza del litoral reviste a veces situaciones que retrasan su atractivo. Muchas playas mediterráneas son todavía lugares insanos y la amenaza palúdica de las aguas estancadas e infectadas de mosquitos obliga a desecar y drenar las zonas pantanosas. La Nouveau guide du voyageur en Espagne et Portugal de Lanneau Rolland alude en 1864 al poco fondo del mar de Alicante y a sus aguas viscosas y fétidas, donde los baños son imposibles (Valero, 1991). Y la naturaleza playera también se domestica en el entorno del balneario. Elementos artificiales como diques, espigones y rompeolas protegen las casetas de baño y el propio balneario de la fuerza del mar, o los aíslan de los puertos pesqueros y de los usos industriales que compiten en el borde costero. Los paseos marítimos, a modo de miradores y antesala a la playa, frenan el avance de las arenas y marcan la frontera entre lo natural y lo urbano. A finales de siglo, se incorporan al paisaje la casa de veraneo y luego las primeras villas, tanto en primera línea como en los entornos naturales con vistas al mar y a donde llega la brisa. La transformación de la naturaleza progresa especialmente en los enclaves con mejores accesos, especialmente a los que llega el ferrocarril.

\section{B. La oferta y promoción de los enclaves de aguas}

A mediados del siglo XVIII el marqués de la Ensenada, secretario del Consejo de Castilla, encarga la elaboración de un repertorio de manantiales minerales que se plasman en la inconclusa Historia universal de las fuentes y baños minerales de España de $1764^{3}$ (Gómez de Bedoya, 1764). A partir de entonces comienza el interés por la explotación de los enclaves de aguas. La labor legislativa de las Cortes de Cádiz juega desde 1810 un papel determinante en el desbloqueo del problema de la propiedad, al suprimir el dominio directo señorial sobre las aguas, que

\footnotetext{
${ }^{3}$ La obra es la primera de este género en España y recoge, entre otros aspectos, la ubicación de las fuentes y baños, las virtudes de las aguas, el modo de administrarlas y la descripción de los lugares.
} 
pasa a ser comunal. Se inicia entonces un proceso imparable de cesión del dominio útil a particulares a cambio de un canon que obliga a la administración a elaborar el primer censo de casas de baños en 1816 y el primer reglamento un año después (Larrinaga, 2011). Con la corriente desamortizadora muchos municipios privatizan los bienes comunales, incluidas las fuentes minerales, incitando a la creación de nuevos establecimientos y la reforma de los antiguos. A mediados de siglo, el Tratado completo de las fuentes minerales de España (Rubio, 1853) cifra en el $61 \%$ los centros de aguas en manos de particulares, entre los que se encuentran los de mejores condiciones ${ }^{4}$.

En la segunda mitad del siglo XIX, el balneario se ha convertido en un negocio importante y lucrativo. El anuario oficial de casas de baños de 1887 revela que la mitad de las 160 que recoge están gestionadas por sociedades anónimas y otras formas societarias. Y también las ventas, reventas y los conflictos por su uso y disfrute denotan su rentabilidad ${ }^{5}$. La tendencia creciente desde mediados de siglo en explotar establecimientos de aguas fuerza al Gobierno a intensificar los controles y exigir la declaración de utilidad pública de las aguas para abrir un establecimiento que, además, deberá disponer de un médico director y de análisis de aguas. Estas imposiciones disgustan a los dueños por considerarlas una intolerable injerencia que atenta contra los derechos de propiedad. En 1874, la Liga de Propietarios de Balnearios crea la Asociación Nacional de la Propiedad Balnearia exigiendo la derogación de los privilegios de los facultativos, al tiempo que la Asociación de Dueños de Balnearios de Cataluña reivindica la «libertad balnearia» para contratar médico, solicita la rebaja en la tarifa de los ferrocarriles para el transporte del agua embotellada y el traslado de bañistas, y la revisión de la contribución industrial (Alonso, 2011).

La explotación de los establecimientos de baños de mar, primero con casetas móviles, luego casas de baños y

\footnotetext{
${ }^{4}$ Del total de 89 centros registrados, 54 son de particulares, de los que 29 se ponen en uso durante la primera mitad del siglo. Otros 21 pertenecen a los pueblos, cinco a provincias, cuatro a la nación, dos al Real Patrimonio, otros dos a institutos y sólo uno está en poder del clero. El tratado contabiliza 1.118 manantiales distribuidos por 48 provincias, entre las que destacan Guipúzcoa con 84 fuentes, seguida de Pontevedra, Granada y Ciudad Real con más de medio centenar.

${ }_{5}^{5}$ Sirvan algunos ejemplos: el balneario de Coronte lo compra en 1878 una sociedad de Santander y a principios del siglo xx se vende a un empresario comercial (Caz, 1994). El balneario de Panticosa en 1854 es de la Sociedad Guallart y Compañía y lo compra en 1899 Aguas de Panticosa, S. A., cuando su valor se ha multiplicado por 7,5 desde 1854 (Monserrat, 1995). En los balnearios de Banyoles, Caldes de Montbui, La Garriga o Vallfogona los conflictos por el uso de los manantiales llevan a múltiples disputas entre las casas consistoriales y los propietarios (Molina, 2004).
}

más tarde con balnearios, difiere de los del interior al estar localizados en terrenos de titularidad pública, haciéndose en términos de concesión por el Gobierno Civil, la Jefatura de Costas y Obras Públicas, la Comandancia de Marina y las alcaldías. Pero las dependencias se amplían mucho más de lo contratado, los permisos se consiguen con facilidad, no se evitan los monopolios de explotación como marca la ley y se llegan a producir conflictos de competencias entre las distintas instituciones que entran en juego ${ }^{6}$.

La dialéctica playística desarrollada en Europa, en la que se reconoce un esquema bipolar y pendular de playas frías y calientes, en España adopta la forma unitaria de veraneo, polarizada en dos focos: el cantábrico y el mediterráneo (Lavaur, 1977). Primero es la costa atlántica, con los primeros bañistas alrededor de 1830 en las playas guipuzcoanas, principalmente en San Sebastián, como ponen de manifiesto el Hand-Book de Samuel Edward Cook y el libro de Henry Wilkinson, ya con renombre en 1846 las de Deva y Zarauz y en 1849 las de Mondragón, Arechavaleta y Cestona (Larrinaga, 2010). En Vizcaya se detecta un incremento de bañistas desde la década de 1840 en Las Arenas, Algorta y Portugalete, todas próximas a Bilbao (Larrinaga, 2002). En Cantabria el fenómeno es más tardío: las primeras playas frecuentadas son las de Santander y Castro Urdiales en 1868 y pronto lo serán las de Suances, Comillas y Laredo (Gil de Arriba, 2000).

Algunas playas del atlántico andaluz también conocen un desarrollo temprano con las visitas de los estratos sociales más encumbrados y minoritarios de los andaluces del interior que se acercan a las de Cádiz y Sanlúcar. En esta última, las primeras casetas de baños son de 1821 y da cuenta en 1844 George Borrow de la instalación de muchas según el modelo vigente en el norte de Europa. Un primer establecimiento de baños digno de acoger a ciudadanos y forasteros distinguidos en Cádiz lo recoge el viajero y escritor Germond de Lavigne para 1854, y hay constancia de baños en Chipiona desde 1845 (Valero, 1991).

En las playas mediterráneas, las primeras noticias de barracas de baños al pie de la montaña de Montjüic apa-

\footnotetext{
${ }^{6}$ En 1901 el Ayuntamiento de San Sebastián quiere controlar la playa de las posibles cesiones del Gobierno provincial que ponen en peligro el recurso fundamental del balneario La Perla del Océano, que disfruta de una concesión del Estado a perpetuidad desde 1867 y da fama a la localidad (Valero, 1991). En la playa del Sardinero la explotación de los baños depende de la Junta Municipal de Beneficencia hasta que, en 1868, los hermanos Pombo obtienen una concesión para levantar un edificio balneario; a principios de siglo la gestión pasa a la sociedad anónima El Sardinero, propietaria del Casino y del Gran Hotel, consiguiendo el uso casi monopolista de la playa sin encontrar obstáculos por parte del municipio (Gil de Arriba, 2000)
} 
recen en el Diario de Barcelona en 1810, y a mediados de siglo son conocidas las de Caldetes, Arenys de Mar, Lloret, Sant Feliú, Sitges, Palamós, Cadaqués y las de la ciudad de Tarragona (Tatjer, 2009). El diario valenciano La Opinión informa en 1863 de la apertura de la temporada de baños en la playa del Grao, con una afluencia que impide a los trenes dar cabida a la multitud que regresa a la ciudad (Lavaur, 1977).

Si hasta el momento los grandes establecimientos de baños convivían con otros más humildes, adonde acudían las clases populares con fines exclusivamente terapéuticos y durante estancias cortas, sin competir entre sí estas dos categorías de balnearios, en el último tercio del siglo la mayor demanda de alojamiento y nuevas actividades de ocio decantan la asistencia a favor de los balnearios playeros, localizados en poblaciones costeras con más facilidad para ofrecer estos servicios. Sólo los más sólidos y afamados balnearios de aguas minerales incorporarán hoteles de vacaciones, casinos y otras instalaciones de entretenimiento para captar a los visitantes de mayor poder adquisitivo. Esta conducta supone un repliegue del balneario sobre sí mismo, al concentrar en sus límites las nuevas modalidades de ocio y dejar de depender de sus alrededores naturales como marco de actividades, que pasan a un segundo plano ${ }^{7}$.

La promoción de los enclaves balnearios se hace a través de variadas formas de propaganda. Desde la editada por los propios centros en forma de folletos, guías balnearias y anuncios en prensa, hasta artículos y noticias en periódicos y revistas ilustradas que recogen ecos de la sociedad balnearia y el lujo de los establecimientos. La Guía ilustrada de las aguas mineromedicinales y balnearios de España de 1896 incorpora la situación geográfica de los balnearios, clima de la zona, características de las aguas, temporada oficial, indicación de los medios de transporte para su acceso, horario de diligencias y ferrocarriles, excursiones, alojamiento y médico director. Las guías de los centros añaden información sobre las características y condiciones del balneario y utilizan argumentos para atraer al visitante. La del modesto balneario de Fuente del Toro de El Molar lo razona así:

\footnotetext{
${ }^{7}$ El de Mondariz, en el interior de Galicia, incorpora todas las comodidades de la ciudad: lujosos alojamientos, fotógrafo, peluquería, librería, servicio de correos y telégrafos, una sucursal de la Compañía Telefónica Nacional para telefonemas y conferencias y un cuartel de la Guardia Civil. En el recinto también hay múltiples cafés y restaurantes, zonas de juegos de mesa, deportes al aire libre y se ofrecen conciertos de música. A dos kilómetros de la villa termal la propiedad dispone de la finca La Granja de As Pías, donde los clientes pueden jugar a ser granjeros, hacer excursiones por el bosque o dar paseos por el lago (Vilar, 2011).
}

\begin{abstract}
No tenemos en este Balneario los bosques de Wiesbaden, ni las agrestes y tremendas emociones que proporciona al tourista el visitar en Mont-Doré la cima del Capuchino o la fuente del Dogne; pero en cambio se pasa la vida más apaciblemente, y los enfermos que vuelven curados a sus casas, lo hacen con más alegría que si hubiesen visitado la primera maravilla del mundo. (Guía, 1897)
\end{abstract}

Un folleto del balneario de Mondariz insiste en su prestigio y calidad de sus aguas, «las más alcalinas de España», y en su álbum-guía subraya «Las aguas de Mondariz para obsequiar a sus amigos, a la prensa nacional y extranjera, y a los favorecedores del establecimiento minero-medicinal», e introduce mapas del trazado de la red de carreteras y ferrocarriles españoles, y planos, ilustraciones y fotografías del establecimiento y sus alrededores; el álbum añade traducciones en inglés y francés cuando la empresa asiste en 1906 al XV Congreso Internacional de Medicina de Lisboa (Vilar, 2011).

La prensa es un medio de gran alcance para divulgar los balnearios y también la utilizan los servicios de diligencias para acercar a los bañistas desde las estaciones de ferrocarril más cercanas. Hay anuncios de los baños con traducciones en varios idiomas. El Diario de Tenerife en 1887 los incluye en inglés, francés, alemán e italiano. Y aparecen publicaciones periódicas especializadas, como El Verano y El Sardinero Alegre, editados en Santander desde 1865 .

\section{La accesibilidad a los balnearios}

La facilidad de acceso es un factor clave para el éxito de los enclaves de aguas. De hecho, la explotación de algunas fuentes minerales fue descartada por su mala relación con las vías o rutas de cierta entidad. Desde el reglamento de baños de 1917 se insta a diputaciones y ayuntamientos a abrir nuevas vías de comunicación y a mantener en buen estado las existentes. La llegada del ferrocarril impulsa muchos balnearios y la existencia de una estación o apeadero cercano propicia la fidelización de la clientela. Siempre que la orografía lo permita, el establecimiento de baños tratará de atraer al ferrocarril a sus puertas y cuando no sea posible dispondrá de flotas de carruajes entre la estación más próxima y el balneario.

Los ferrocarriles de vía ancha entran en juego, pero también los de vía estrecha desempeñan un papel importante en el sentido de completar los vacíos territoriales dejados por las grandes compañías, al aproximar el establecimiento balneario a las pequeñas localidades, núcleos comarcales y provinciales servidos por tren, y a los enlaces con otros medios de transporte. Son famosos los $c a$ rrilets de la Companyia de los Ferrocarrils de Catalunya, 
que ya en 1863 son el soporte al desarrollo de una cierta actividad veraniega de fines de semana (Molina, 2004).

Pero la accesibilidad a muchos balnearios del interior es complicada. En Panticosa, la propiedad y la influyente clientela solicitan reiteradamente una mejora de las comunicaciones, llegando la primera diligencia en 1862, el ferrocarril a Huesca en 1864 y la implantación de un servicio diario en automóvil desde Sabiñánigo en 1906 (Monserrat, 1995). Las deficientes comunicaciones por el interior de Galicia son un obstáculo para la ampliación de la clientela del balneario de Mondariz, y aunque se ofrece servicios de carruajes desde las estaciones de tren más próximas, una vez fracasada la petición de un ferrocarril de vía estrecha que le comunique con Vigo, la sociedad Tracción Eléctrica del Miño, con el estímulo de la propiedad del balneario, compra en 1908 varios coches de fabricación alemana para transportar a los viajeros desde las estaciones más cercanas (Vilar, 2011).

Por el contrario, las mejoras de la accesibilidad a los balnearios de las playas del norte son más tempranas. La conexión ferroviaria entre Madrid y Santander o San Sebastián permite que las playas del Sardinero o la Concha se conviertan en los principales y afamados espacios de ocio y baños para la burguesía. En Santander el ferrocarril se inaugura en 1852, facilitando la llegada desde Madrid y distintos puntos de Castilla a aristócratas, propietarios agrícolas y burgueses. La apertura del ferrocarril del norte en 1864 es decisiva para San Sebastián, pues antes se llegaba en diligencias que hacían el servicio desde Madrid y Bayona. También las playas atlánticas del sur lo tienen fácil. Las de Sanlúcar están interconectadas con Sevilla por la línea de vapores San Telmo y por dos líneas ferroviarias que las conectan con Jerez de la Frontera en 1877 y con Bonanza desde 1855 (Moreno, 2007). Y las conexiones marítimas de Málaga con Gran Bretaña favorecen la instalación de invernantes ingleses en la capital y alrededores.

El caso de Canarias merece ser considerado por las peculiaridades que presentan la accesibilidad y la promoción de la oferta. La atracción de forasteros como negocio coincide con el desarrollo de la navegación trasatlántica. Las líneas de vapores asociadas a la actividad comercial son inglesas, parten de Liverpool con destino a las colonias africanas y hacen escala en el puerto de Santa Cruz. Son comerciantes ingleses afincados en los principales enclaves costeros de Las Palmas, Santa Cruz y Puerto de la Cruz de la Orotava quienes controlan el negocio portuario y las exportaciones de productos canarios, e igualmente son empresarios británicos residentes en 1887 quienes promueven, entre otros extranjeros, la construcción y explotación de los primeros alojamientos que propician la llegada de compatriotas (Domínguez, 2007). El Diario de Tenerife recoge pensiones y hosterías suizas e inglesas en el puerto de la Orotava y establecimientos de capital inglés y alemán que en principio albergan a enfermos y convalecientes, y más tarde se llenan de turistas. La Laguna también recibe extranjeros en hoteles ingleses y alemanes. Casas señoriales se transforman en alojamientos, como la del marqués de Candia, que la arrienda en 1887 a la Compañía de Hoteles Sanatorium de La Orotava, y tras la fusión con The Taoro Company Limited construye The English Gran Hotel, conocido como Hotel Taoro, para dar hospedaje a los extranjeros delicados en salud y a los que por placer deseen pasar la estación invernal, concebido como un lugar para combinar la suntuosidad y glamour con la desbordante naturaleza canaria (Estévez, 2002).

El número de balnearios en España sigue aumentando hasta finales del siglo. En 1877 los Anales de la Sociedad Española de Hidrología Médica recogen 204 centros distribuidos por 43 provincias ${ }^{8}$, pero a fines de siglo se cierran muchos, en especial los más populares, los que sólo ofrecen baños minerales y los de mayor dificultad de acceso.

\section{LOS CÍRCULOS EXCURSIONISTAS IMPULSORES DE LA PRÁCTICA VIAJERA}

Los principales focos del inicio del excursionismo como práctica de viaje colectivo aparecen en Cataluña, Valencia y Madrid. En sus inicios reúnen a conocidos institucionalistas y académicos y a una minoría de aficionados al arte y la cultura procedente de profesiones liberales, burguesía urbana, pequeña aristocracia e intelectuales. Con el paso del tiempo los círculos excursionistas se abren a una gama de público más amplia en su afán de fomentar el hábito del viaje y la excursión, pero también de dar a conocer los paisajes y localidades de sus territorios.

El excursionismo catalán nace en el último cuarto del siglo xIX al amparo de la influencia de los clubes alpinos

\footnotetext{
${ }^{8}$ La distribución de los balnearios es la siguiente: doce en Vizcaya; once en Guipúzcoa; diez en Granada y Barcelona; nueve en Valencia; ocho en Santander y Jaén; siete en Navarra, Pontevedra, Zaragoza, Ciudad Real, Burgos y Álava; seis en Madrid y Gerona; cinco en Lérida, Cádiz y Almería; cuatro en Huesca, Murcia, Orense, Oviedo, Logroño, Cuenca, Alicante y Córdoba; tres en Tarragona Málaga, Castellón, Cáceres y Badajoz; dos en Teruel, León, Lugo, Salamanca, Valladolid, Zamora, La Coruña y Guadalajara, y uno en Sevilla, Baleares, Albacete y Ávila (Molina, 2004).
} 
europeos y de los ideales patrióticos del movimiento regionalista de la Reinaixença. La Associació Catalanista d'Excursions Científiques se crea en 1876 y dos años después, por escisión, nace la Associació d'Excursions Catalana, agrupándose ambos en 1891 en el Centre Excursionista de Catalunya. El Centre es pionero en la defensa de la naturaleza; reclama en 1902 la protección de algunos espacios emblemáticos del nacionalismo catalán y la creación en 1914 de parques nacionales en Cataluña (Moreno, 2007); anuncia y divulga sus principales actividades a través de carteles de gran calidad, siendo considerada la primera entidad catalana en crear un cartelismo turístico de estilo modernista (Montaner, 2004). Este excursionismo, más cultural y catalanista que lúdico o deportivo, será de gran importancia para el desarrollo del turismo al dar a conocer el país y fomentar el hábito y el gusto por recorrerlo y descubrirlo, e incorporando al imaginario colectivo los Pirineos, especialmente el catalán, apoyado en buena parte en los relatos de viaje de Jacint Verdaguer (Jiménez, 2006).

El Centro de Excursiones Científico-Literarias y Artísticas de lo Rat Penat surge en Valencia en 1880. Su fundador y promotor es Teodoro Llorente, patriarca de la Renaixença y director del periódico La Provincia, donde se publican las crónicas de las excursiones. Los socios recorren el territorio valenciano y otros escenarios cercanos de simbolismo histórico y patriótico; visitan en 1882 los monasterios de Poblet y Santes Creus y ciudades como Valls y Tarragona, y en 1901 municipios como Daroca, Sarrión, Calatayud y Teruel (Roca, 2011). En Madrid se crea en 1893 la Sociedad Española de Excursiones con interés en divulgar los recursos históricos y artísticos del país; admite todo tipo de socios, cualquiera que sea su condición y lugar de residencia siempre que se adhieran al pensamiento de la Sociedad; edita un boletín desde 1893 con los relatos de las excursiones realizadas a pie o en tren, acompañados de dibujos y fotos de los objetos y monumentos notables del recorrido, y cuando las salidas son largas contratan servicios de hoteles y comidas (Boletín, 1893).

\section{LA POLÍTICA TURÍSTICA, LAS INICIATIVAS COLECTIVAS Y EL SECTOR PRIVADO EN LA OFERTA Y PROMOCIÓN DE TURISMO ENTRE 1905-1936}

A principios del siglo xx entra en escena la Administración central, que pone su punto de mira en el visitante extranjero y persigue definir la imagen turística de Es- paña a través de la divulgación de determinados símbolos de identidad nacional. En paralelo, surgen iniciativas colectivas, las sociedades de atracción de forasteros y los sindicatos de iniciativas turísticas, que promocionan sus territorios para fomentar el turismo entre el visitante extranjero y también nacional y aspiran a difundir una imagen turística que recoja su identidad local y regional. Por último, la oferta de turismo se amplía con otros actores, entre ellos las empresas extranjeras, que también entran en el negocio.

\section{LA POLÍTICA TURÍSTICA EN LA PROMOCIÓN DEL TURISMO}

En la actuación del Estado en política turística se suceden iniciativas legislativas donde se ponen de manifiesto aspectos relativos al papel que juegan el paisaje y el patrimonio cultural en la intervención y fomento del turismo, así como en la imagen que se proyecta de España. Se reconocen cuatro periodos identificados con las prácticas de la Comisión Nacional, la Comisaría Regia y el Patronato Nacional de Turismo, diferenciando dos etapas, la monárquica y la republicana.

\section{A. Los inicios de la política turística. La Comisión Nacional para el Fomento del Turismo (1905-1910)}

El nuevo Gobierno liberal y reformista dicta en 1905 las primeras disposiciones para la propagación y desarrollo del turismo, marcando el inicio de una planificación turística estatal. Ese mismo año crea, dentro del Ministerio de Fomento, la Comisión Nacional para el Fomento del Turismo, vigente hasta 1910. La intervención se justifica por la falta de iniciativa privada hacia el turismo exterior, que ve como una oportunidad para atraer ingresos. Se apoya en que España, por su topografía y clima, monumentos artísticos y riqueza de recuerdos históricos, reúne condiciones para captar turistas.

La comisión la preside el ministro del ramo y está formada, entre otros, por importantes agentes turísticos privados $^{9}$. Su objetivo es fomentar en España las excursiones artísticas y de recreo del público extranjero, y sus

\footnotetext{
9 Son los directores de las cuatro grandes compañías ferroviarias del país, el presidente de la Sociedad Española de Excursiones y Secretario General de la Real Academia Española de Bellas Artes, el presidente del Touring Club HispanoPortugués y director literario de la revista ilustrada Le Touriste, el presidente del Real Automóvil Club de España, un ex ministro de Hacienda, el director de la Biblioteca Nacional y, como secretario, el director del periódico La Época y cronista oficial de los viajes de Alfonso XIII (González, 2005)
} 
competencias son gestionar con las compañías de ferrocarriles tarifas especiales y trenes rápidos y confortables, conectar con entidades públicas y privadas la mejora de los alojamientos y servicios para los viajeros y difundir en el extranjero las bellezas artísticas y naturales de la nación. Las primeras medidas reguladoras de la industria turística se aprueban en 1909, en concreto dos reglamentos, el de hospedaje y hostelería y el de guías intérpretes de turismo real (Cal, 1997). En 1910, dada la insuficiencia y escasez de hoteles confortables fuera de las grandes ciudades, propone la Red de Alojamientos del Estado mediante la habilitación como paradores de edificios recuperados de interés histórico-artístico, localizados en comarcas y parajes no muy poblados pero con interés turístico, y con la construcción de albergues de carretera para los visitantes que viajen en automóvil.

En paralelo se mueven colectivos locales interesados en impulsar el turismo. A iniciativa de la burguesía progresista de Zaragoza se celebra en 1908 el Primer Congreso Internacional de Turismo en el marco de la Exposición Hispano-Francesa, con el objetivo de encontrar una estrategia común de articulación del turismo español desde los distintos sectores. Se adhieren el ministro de Fomento y delegados del sector público y asisten sociedades deportivas y alpinas, touring clubs, industria hotelera, comerciantes y periodistas, así como sindicatos franceses de fomento del turismo. Aquí nace el embrión de un interesante asociacionismo profesional y se impulsa la creación de sindicatos de turismo españoles con el deseo de culminar en una federación franco-española de sindicatos (González, 2005).

$\mathrm{Si}$ en el congreso se pone de manifiesto el tono regeneracionista de la iniciativa para hacer del turismo una gran empresa nacional, en Cataluña aparecen las primeras obras que lo suscriben. Pionera, de 1903, es La industria de los forasteros de Bartolomé Amengual, uno de los fundadores de la Sociedad de Atracción de Forasteros de Barcelona. En 1909 Carlos Arcos y Cuadra publica De las grandes ventajas que produciría el desarrollo del turismo en España, al que considera uno de los componentes constitutivos de la vida moderna y como elementos articuladores cita los hoteles, los transportes y la propaganda. El presidente del Real Automóvil Club de Cataluña y antes alcalde de Barcelona, Salvador Samá, escribe en 1910 Consideraciones acerca de la necesidad del fomento del turismo como fuente de riqueza nacional y da propuestas directas y prácticas para la mejora del turismo español, entre otras, la creación de un gran circuito nacional automovilista (Moreno, 2007).
En el mismo sentido se encuentra la propuesta para fortalecer el turismo presentada en 1910 a la Cámara por el diputado liberal Prieto Mera. En ella reconoce la labor desempañada por las sociedades de iniciativas provinciales ya creadas, apoya el concurso del Estado junto a la iniciativa privada y sugiere crear en cada provincia o capital una junta para el fomento del turismo. Aunque la propuesta no se acepta tal cual es formulada, el ambiente de inquietud y las conclusiones a que llega en la misma línea el IV Congreso Internacional de Turismo de Lisboa en 1911 inciden en el Gobierno para sustituir la Comisión Nacional por la Comisaría Regia del Turismo (Cal, 1997).

\section{B. La Comisaría Regia de Turismo y la Cultura Artística} (1911-1928)

La Comisaría Regia se crea en 1911 integrada en la Presidencia del Gobierno. Cuenta con un comisario y dos funcionarios por cada uno de los ministerios de Estado, Gobernación, Fomento e Instrucción Pública. Se justifica, de nuevo, por la necesidad de hacer accesibles a los extranjeros los tesoros del arte, el patrimonio espiritual y las bellezas naturales, insistiendo en que tal empresa no pueden abordarla ni la iniciativa individual ni la acción aislada de diversos centros ministeriales, sino un organismo superior. A la Comisaría le compete velar por la custodia, promoción y divulgación de los tesoros artísticos, monumentales y pintorescos de la nación y contribuir a facilitar comunicaciones rápidas y cómodos alojamientos a los forasteros (Jaimez, 2004).

$\mathrm{Su}$ principal actividad se centrará en el patrimonio cultural y, en este sentido, cabe destacar la labor desempeñada por su comisario Vega Inclán, de clara orientación institucionista. La concepción de que un museo moderno no debe ser una anaquelería de tienda, sino un espacio que dé intensidad a la exhibición del arte que contiene, se pone en práctica en la Casa y Museo del Greco y en la Sinagoga del Tránsito de Toledo, la Casa de Cervantes en Valladolid y los museos Romántico y de Turismo en Madrid, encargando a este último la elaboración de un catálogo que permita conocer localidades y regiones poco exploradas. También promueve la rehabilitación del barrio sevillano de Santa Cruz, primer casco medieval sometido a una reforma con fines turísticos, y las restauraciones de la Alhambra y el Generalife de Granada (Ortega, 2013).

La Comisaría retoma la propuesta de la Red de Alojamientos Turísticos del Estado, que ahora se perfila y pone en marcha. El parador de nueva planta de Gredos se inaugura en 1928, con el objeto de abrir al turismo 
los paisajes, la caza y la pesca de la sierra, y se inicia la recuperación de un edificio barroco en Mérida para convertirlo en parador. También la Comisaría participa en las decisiones tomadas desde instancias superiores sobre el patrimonio y el paisaje natural, apoyando las declaraciones de los primeros parques nacionales de Covadonga y Ordesa en 1918 y de los sitios y monumentos naturales de interés nacional en 1927 (Moreno, 2004).

La mejora de los transportes y comunicaciones para los forasteros vienen de la mano del Gobierno primorriverista con las millonarias inversiones estatales, básicamente viarias y ferroviarias. Se pone en marcha el Circuito Nacional de Firmes Especiales; se crea el Consejo Superior Ferroviario, que canaliza la ayuda financiera estatal a las empresas; se aprueba el Estatuto Ferroviario, por el que el Estado fija las tarifas y se solicita en 1911 a la Compañía Ferroviaria Madrid-Zaragoza-Alicante un tren rápido de lujo entre París y Barcelona y la comunicación directa por tren entre Valencia y Sevilla (Cabanes y González, 2009). También prospera el transporte aéreo por los convenios con Italia, Alemania y Francia, los primeros vuelos regulares dentro de España y los primeros transoceánicos. Se aprueba el reglamento de las líneas de autobuses de viajeros, que empezaban a hacer la competencia al tren. Y también a lo largo de los años la Comisaría presenta al Gobierno varios proyectos que no ven la luz ${ }^{10}$.

La promoción del turismo en el exterior se consigue gracias a los contactos personales que establece el comisario Vega Inclán para estar presente en ferias, exposiciones y reuniones internacionales. La mayor empresa es la exposición española de turismo celebrada en Londres en 1914 con el eslogan Sunny Spain. Su principal reclamo no son los monumentos, ni la gastronomía, ni las fiestas de toros, sino el sol de España. Pero apenas inaugurada la exposición, estalla la guerra entre Austria y Serbia, que obliga a cerrarla. También promueve la Exposición de Arte Español celebrada en París en 1919 con participación de la Oficina Nacional de Turismo francesa y el Touring-Club francés y abundante publicidad en la prensa francesa y española. Asimismo, se consolidan los cursos de verano para extranjeros de la Universidad Menéndez

\footnotetext{
${ }^{10}$ El más ambicioso es convertir el eje Algeciras-Sevilla-Cádiz en un gran centro de turismo internacional como puerto de entrada a los transatlánticos americanos y también la puerta hacia África y sus estaciones turísticas de invierno, para lo que es necesario construir un puerto de alto calado en Algeciras y enlazarlo por ferrocarril con Sevilla, Córdoba y Granada (Moreno, 2005). Tampoco surten efecto las gestiones para modernizar los balnearios, residencias y estaciones de altura.
}

Pelayo, que, en colaboración con la de Liverpool, se celebraban desde 1922 en Jaca, pasando dos años después a Santander (Correyero y Cal, 2008).

La intención de difundir entre los turistas la riqueza paisajística y artística del país se plasma en una labor editorial fecunda que contempla la traducción de muchas publicaciones en varios idiomas. Los títulos de la serie Propaganda y Defensa de la España Monumental, dedicada a diferentes ciudades, se editan también en inglés, o los de la Biblioteca El Arte en España, conjunto de 36 monografías en forma de pequeños libritos con profusión de láminas dedicadas a ciudades históricas y monumentos histórico-artísticos, contiene textos breves en francés e inglés. A la serie Propaganda de Viajes por España pertenecen los Itinerarios de Arte por España, que se inician en Madrid y enlazan localidades de interés artístico y monumental, y los Itinerarios de Viajes Populares, dedicados a excursiones desde Madrid hacia ciudades monumentales más cercanas como Toledo, Ávila, Guadalajara, Alcalá o Segovia ${ }^{11}$. La Sección de Montaña, de dimensión más expresamente paisajística, comprende folletos divulgativos dedicados a Gredos, Sierra Nevada o los Picos de Europa, e incluye algunos libros de mayor interés como los dedicados a Sierra Nevada y a La Pedriza del Real de Manzanares (Ortega, 2013).

Pero la publicación concebida para servir de propaganda de la Comisaría en el exterior es la obra España, de Sánchez Cantón, subdirector del Museo del Prado, editada en 1923, de la que se hacen traducciones en inglés, francés, alemán y esperanto. Se presenta España a través de textos sobre geografía, historia, arte, arquitectura, escultura, pintura, artes industriales, vida, fiestas y comidas, y sin una sola imagen (Sánchez, 1925). Alude el autor que la diversidad despierta apetencias en el hombre moderno y España puede suministrarla. Sin embargo, la mayor parte de los textos remiten a Castilla y Andalucía, y como recursos turísticos presenta una selección sesgada de elementos naturales y artísticos. Por ejemplo, se citan profusamente Guadarrama y Gredos,

\footnotetext{
${ }^{11}$ La labor editorial es motivo de polémica desde muy pronto. No se la considera moderna, práctica y accesible, tal y como demandan los nuevos tiempos. En el Quinto Congreso de Turismo de Madrid de 1912, la conferencia del arquitecto madrileño Vicente Lampérez, «La geografía monumental de España y los itinerarios del turismo», defiende una promoción del turismo cultural a base de itinerarios o grandes rutas y no mediante focos aislados, porque, sostiene, los itinerarios de turismo los marcan o imponen, no las clasificaciones histórico-artísticas, sino las líneas de ferrocarriles, sus enlaces y entronques, los horarios de los trenes y hasta las combinaciones mercantiles de la agencia Cook y similares, y propone adaptar los itinerarios no a una historia del arte sino a una geografía del arte (Moreno, 2004).
} 
en absoluto los Pirineos. Ésta será la imagen turística oficial que se divulga en el extranjero. La imagen de una España que se mira en el espejo del pasado y se apoya en sus símbolos, especialmente la historia gloriosa y los monumentos como definidores de lo español, sin demostrar interés en incorporar la diversidad que ofrecen otras regiones del país.

Entrados los años veinte los resultados de la Comisaría en el fomento del turismo son cuestionados desde varios frentes, especialmente por el sector empresarial, que ya venía haciéndolo, y más ahora ante la inminencia de las exposiciones universales de Barcelona y Sevilla. El concesionario y fletador de buques asentado en Barcelona Herrero Anguita presenta en 1926 al Gobierno el Estudio del turismo y proyecto para su desarrollo en España mediante la creación de un consejo nacional y constitución de la Compañía Hispano-Americana de Turismo, y propone la creación de un organismo estatal para centralizar y coordinar todo el quehacer turístico, inspirado en la Office National du Tourisme francesa. Ante el silencio oficial, el proyecto se envía al presidente de la Compañía Trasatlántica Española, el conde Güell, quien lo acoge con entusiasmo y lo distribuye en ayuntamientos, diputaciones y otros organismos, así como al rey y al presidente del Gobierno, Primo de Rivera (Moreno, 2004). Dos años después la Comisaría Regia es sustituida por el Patronato Nacional de Turismo.

\section{El Patronato Nacional de Turismo en la etapa monárquica (1928-1931)}

El Patronato Nacional de Turismo reproduce el esquema de las administraciones turísticas de otros países europeos; de hecho se basa en el Ente Nazionale per la Industria Turística italiano ${ }^{12}$. El organismo depende del Consejo de Ministros, con la presidencia en manos de Alberto de Borbón, pronto sustituido por el conde Güell ${ }^{13}$.

El Patronato prosigue con la tarea de construir una hostelería estatal y para ello crea a finales de 1928 la

\footnotetext{
${ }^{12}$ Incluye a consejeros que representan todos los vértices del negocio turístico (transporte, navegación aérea, industria hotelera, firmes, automovilismo, historia y arte). Hay tres clases de administraciones: la central en Madrid, la regional en las capitales de las seis subdelegaciones, y la provincial a cargo de las Juntas Provinciales o Juntas Locales (Moreno, 2007).

13 Juan Antonio Güell López, segundo conde de Güell y tercer marqués de Comillas, es uno de los hombres más influyentes de Cataluña y una de las mayores fortunas de España. Fue presidente del Patronato desde noviembre de 1929 al verano de 1930. Como importante naviero y empresario catalán quiere hacer del país un puerto de llegada de grandes transatlánticos americanos, pero también le mueve ampliar el volumen de negocio de su compañía (Moreno, 2011).
}

Junta de Paradores y Hosterías del Reino. La forma de proceder con respecto a los paradores sigue siendo la misma que en anteriores administraciones, incorporando ahora las hosterías con servicios sólo de restauración ${ }^{14}$. Colabora con el Ministerio de Fomento para elaborar un plan de rutas turísticas y establecer donde situar los albergues, utilizando para ello la información de la Guía Michelin de 1927, la guía hotelera de 1929 y la guía de carreteras del Real Automóvil Club de España. Los albergues pensados para automovilistas, complemento necesario del Circuito de Firmes Especiales, se sitúan en puntos estratégicos de las principales carreteras y serían de construcción económica ${ }^{15}$ (Moreno, 2010).

El Patronato plantea atender más eficazmente la actividad turística mediante el estímulo a la industria hotelera. Para ello implanta el libro de reclamaciones e instala placas en los hoteles recomendados por el Patronato; edita la primera Guía oficial de hoteles, pensiones, casas de viajeros, restaurantes, bares y garajes de España con texto en español, francés, inglés y alemán; crea el crédito hotelero en 1929 para estimular la construcción de alojamientos en localidades de interés turístico; construye en 1929 el Hotel Atlántico de Cádiz para atender a los turistas de los trasatlánticos que venían de América; crea la Compañía Hispanoamericana de Turismo, órgano nacional de carácter industrial y mercantil, inspirado en el Ente Nazionale per le Industrie Turistiche. Para la mejora del transporte solicita al Gobierno la ampliación de los itinerarios semicirculares de ferrocarril, fundamentales para los viajes que organizaban las agencias desde el extranjero; hace peticiones y sugerencias para reformar y construir carreteras e incorporar indicadores turísticos; solicita que las grandes navieras trasatlánticas de todo el mundo fondeen en los puertos españoles; y en 1929 participa en el Plan de Comunicaciones Aéreas para acabar con la influencia y dependencia de los interese extranjeros (Moreno, 2007).

El Patronato hace fuertes inversiones en información, propaganda y publicaciones y en la preparación de las ex-

\footnotetext{
${ }^{14}$ Se inauguran en 1930 los paradores de Oropesa (Toledo) en una antigua casa solariega del siglo xIV y el de Úbeda (Jaén) en un antiguo palacio renacentista. Del mismo año son la hostería de La Rábida (Huelva), de nueva traza pero cercana al monasterio de esa localidad, y la de Alcalá de Henares (Madrid), instalada en el patio de la universidad.

${ }^{15}$ Los doce albergues de carretera previstos son los de Manzanares (Ciudad Real), Bailén (Jaén), Quintanar de la Orden (Toledo), Aranda de Duero (Burgos), Benicarló (Castellón), Medinaceli y Almazán (Soria), La Bañeza (León), Pantano de la Peña (Cuenca), Puerto Lumbreras (Murcia), Antequera (Jaén) y Puebla de Sanabria (Zamora)
} 
posiciones universales de 1929. En el campo de la información y propaganda abre siete agencias en el extranjero, las de París, Londres, Múnich, Roma, Gibraltar, Nueva York y Buenos Aires, para divulgar el turismo español y captar clientela, y alrededor de medio centenar en España para controlar los puertos de llegada y salida de viajeros, la frontera con Francia y las capitales más turísticas del interior, con el fin de distribuir folletos de propaganda y exhibir los carteles que confecciona el Patronato. Da licencias a las agencias extranjeras American Express y Wagon-Lits localizadas en el extranjero para vender billetes de tren y de barco hacia España. Y para atender al turista aprueba el reglamento del Servicio de Guías, Intérpretes y Correos. Como medio de propaganda también promueve exposiciones de fotografías turísticas en Madrid y de arte en Valencia, Toledo, Santillana del Mar y Granada; firma contratos con los grandes trasatlánticos de la Navigazzione Generale Italiana para distribuir en sus compañías de embarque folletos y carteles turísticos, invita a la prensa extranjera a Madrid, Barcelona, Sevilla y Toledo a cambio de divulgar estos viajes en sus países e integra publicidad en la prensa extranjera (Pellejero, 2002; Moreno, 2007).

La línea editorial presta atención a los aspectos artísticos y monumentales y menos a los naturales. Aumenta el número de títulos de la colección El Arte en España, edita guías y álbumes ilustrados de ciudades y folletos temáticos sobre Castillos, Jardines, Catedrales, Palacios reales, El Camino de Santiago, Las cuevas de Altamira, La sierra de Gredos, La sierra del Guadarrama, Las romerías andaluzas, Los deportes o El veraneo. Y también folletos, a modo de pequeñas guías de muchas ciudades, especialmente del interior, en las que incluye en la contraportada un plano de la ciudad con indicación de los monumentos y postales y cartas-sobre con fotos de edificios importantes.

Si hasta la fecha la administración turística había desatendido la promoción a través de carteles, ahora contrata a diseñadores y dibujantes de calidad, aportando una imagen de la oferta de turismo más allá de la contemplada en los anteriores soportes propagandísticos, centrada fundamentalmente en el patrimonio cultural de la España interior, que ahora se muestra más cosmopolita al abrirse a los territorios que contactan con el mar. Aunque en el cómputo de la cartelería publicada (Carulla, 1994 y 1998; Instituto de Estudios Turísticos, 2005 y página web) abunda la incorporación del eslogan genérico «Visite España», en varios idiomas, sobre imágenes de conjuntos monumentales y paisajes costumbristas, se añaden ahora localidades del litoral que han adquirido renombre por el atractivo de sus playas. Los carteles, ya a finales de los años veinte, de Alicante, Huelva, las islas Baleares, Bilbao, las rías gallegas, Málaga, Santander, San Sebastián o Sitges muestran paisajes abiertos al mar, con una luz radiante y donde se practican el baño y los deportes y se recorren los paseos marítimos. El Patronato es consciente de que el cartel, soporte propagandístico de fácil y rápida comprensión, es el más adecuado en el extranjero, por lo que no desatiende en su promoción turística la oferta litoral que ya empieza a consolidarse en España.

La trascendencia internacional que tuvo la Exposición Universal de Barcelona de 1888, reflejada en la afluencia de visitantes extranjeros y en la difusión de la imagen de la ciudad fuera de España, incita al Patronato a interesarse por las exposiciones universales de 1929, celebradas en Barcelona y Sevilla, aunque su intervención se centrará en la última. En paralelo, Barcelona prepara la Exposición Internacional de la Industria Eléctrica, que recibe el nombre de Exposición de Barcelona, sin subvención estatal y en la que el Patronato apenas tiene protagonismo.

Si la exposición de 1888 sirvió para proyectar la imagen dinámica y moderna de la ciudad anfitriona a nivel internacional y para consolidad la actividad turística como un fenómeno con gran relevancia económica, el Patronato utilizará la sevillana de 1929 como vehículo de propaganda de la dictadura primorriverista, a través de los valores nacionales y turísticos de España en general y de Sevilla en particular. El evento de 1888, debido a la iniciativa de un empresario, al que apoyaron varias asociaciones culturales ${ }^{16}$, fue un éxito y demuestra la implicación de los agentes locales en la profesionalización de la actividad turística alcanzando la ciudad una considerable mejora en infraestructuras de alojamiento y transporte. Además, se consigue proyectar en el exterior una nueva imagen de la identidad catalana con la promoción de sus elementos patrimoniales más significativos, pero añadiendo nuevos referentes al gusto de la sociedad europea emergente, como son la práctica del deporte, el automovilismo y la aeronáutica (Garay y Cànoves, 2009). Para su promoción se realizó una intensa propaganda en el extranjero, cubriendo toda Europa y América, y dentro del país se crearon delegaciones en muchas ciudades y se editó el periódico La Exposición.

\footnotetext{
${ }^{16}$ La iniciativa nace de Eugenio Serrano de Casanova, que había participado en eventos similares celebrados por toda Europa. La Exposición de Fráncfort, dedicada al termalismo, la diseñó prácticamente entera, al haber regentado anteriormente el balneario de la Fonsanta en Cataluña ( $L a$ Voz de Galicia, 2013).
} 
Para la Exposición de Sevilla de 1929 el Patronato publica El Libro de Oro de la exposición, declarado catá$\log$ oficial ${ }^{17}$, y difunde folletos y carteles realizados por destacados dibujantes, imprime sellos conmemorativos, coloca publicidad en revistas y prensa, en trenes y compañías de navegación y en más de cincuenta países, entre europeos y americanos, y otros como Indochina, Lituania, Madagascar, Mesopotamia, Turquía o Tánger. La mayor dedicación publicitaria se centra en los carteles, editados en varios idiomas, que subrayan el estilo regionalista-historicista acorde con la arquitectura del recinto a cargo de Aníbal González Álvarez, principal referente del regionalismo andaluz del momento.

La exposición desató críticas desde muchos frentes. Se pone en entredicho la campaña promocional que, amparada en el casticismo, rechaza la modernidad y las influencias del cartelismo internacional. La insuficiente afluencia de público se atribuye a la desacertada campaña promocional en el extranjero. También se reprueba la escasa atención prestada a las propuestas locales y regeneracionistas para la capital andaluza, que aspiraban a dar una imagen de progreso y modernidad con la construcción de un balneario, un hipódromo y otros espacios de disfrute para una élite de invierno y con la promoción del puerto para la recepción del turismo de cruceros americanos, para lo que sólo se necesitaba mejorar las comunicaciones con el estratégico golfo de Cádiz (Rodríguez, 1994).

Mientras la exposición de Sevilla adopta el nacionalismo como reclamo turístico y asienta sus bases sobre una pretendida recuperación de la grandeza de la historia española, la exaltación de los valores históricos nacionales, el pasado glorioso, la España de los edificios señoriales y el estrechamiento de lazos culturales y sentimentales con América, la de Barcelona tiene una ambición europeísta, internacionalista y abierta a la modernidad, que opta por la puesta al día en el engranaje artístico europeo haciendo propios, con matices autóctonos, los principios artísticos del modernismo. Lejos de la monumentalidad historicista que inspiró la exposición sevillana, la de Barcelona inauguraba una novedad ya ensayada con éxito en otras exposiciones europeas, como es la de combinar el presente y el pasado. Junto al recinto monumental y moderno, representado por el Palacio Nacional, se incor-

\footnotetext{
${ }^{17}$ Contiene más de 2.500 ilustraciones y fotografías y 250 artículos firmados por altas personalidades de la política, la economía y la cultura de la época. Entre ellos destacan Federico García Lorca, Pío Baroja, Manuel Machado, Ramón Gómez de la Serna, Eduardo Marquina, Ramón Pérez de Ayala, Concha Espina y Eugenio d'Ors (Martín, 2008).
}

pora El Pueblo Español como resumen de la tradición arquitectónica local española. Lo monumental frente a lo popular, el palacio enfrentado a las construcciones de pueblos y aldeas nacionales ${ }^{18}$. La gestión del evento se cede a una empresa privada, la Sociedad Anónima de Grandes Almacenes El Siglo, y la propaganda corre por cuenta del Comité de la Exposición.

Por estos años también se fragua la imagen turística oficial de Valencia, que pasa por ser la acuñada en la Guía del turista en Valencia de 1929, declarada oficial por el Ayuntamiento. La ciudad se presenta como «la ciudad de las flores» y se arropa en símbolos costumbristas que recurren a atributos abigarrados y vinculados tiempos pasados. Ese mismo año el Patronato organiza la Exposición de Arte de Levante y se decanta por construir una imagen que se identifique más por sus campos de naranjos, sus estepas de arrozal, el azul luminoso de su costa, la fama de sus artistas y como país de arte, y menos en su torre del Miguelete y su gótica lonja de la Seda. Los carteles del Patronato reflejan esta imagen a la hora de ilustrar sus eslóganes «L'Espagne est belle toute l'année», «Fleurs et fruits de la Mediterranée» $\mathrm{O}$ «Spain glorious spring», con representaciones de su mar y su huerta, entre barracas, naranjos y un sol resplandeciente y se sirve de su tradición como sede del «balnearismo» para una emergente clase media agrocomercial. Pero quizá haya ejemplos anteriores de marca turística en los folletos de la Oficina Valenciana para el Fomento del Turismo que en 1910 rezan «Valencia, el país del arte y de las flores», así como en la marca recogida en el título de la película de 1928 Valencia, país de las flores y del arte, realizada con fines puramente turísticos por parte de la casa Cubells y Albert para propagar Valencia en Hispanoamérica (Puche y Obiol, 2011).

Así pues, el Patronato concibe el turismo como fuente de prestigio nacional, al igual que hiciera la Comisaría Regia, pero difiere de ésta por su perspectiva totalmente nacionalista que aporte prestigio al régimen. De esta forma, la imagen del país no se identifica tanto con la asociación España-Castilla o el mito romántico del sur, sino como una unidad centralista e indisoluble, el Estado, donde se reconoce cierta diversidad a medio camino entre lo regionalista y lo folclórico-pintoresco (Moreno, 2004).

\footnotetext{
18 Fueron las condiciones orográficas de los terrenos de Montjüic las que determinaron qué pueblos estarán representados. El espacio se reparte en dos grandes unidades: un centro castellanizado y una periferia mediterránea protagonizada por Cataluña, donde además se incluye un pueblo andaluz. La transición la representan el País Vasco y Navarra (Moreno, 2004).
} 


\section{El Patronato Nacional de Turismo en la etapa republicana}

El Gobierno republicano de 1931 interviene el Patronato y lo transforma en una Dirección General de Turismo dependiente de Presidencia de Gobierno, pero ese mismo año lo restablece y reorganiza en base a un mayor control en lo administrativo y presupuestario y con una estructura organizativa más simple ${ }^{19}$. Persigue un modelo descentralizado en el que las iniciativas turísticas locales se encargarán de muchas tareas anteriormente desempeñadas por los funcionarios. Sus objetivos presentan pocas variaciones con respecto a la etapa monárquica. Continúa la política de albergues de carretera y paraliza la construcción de paradores al considerar demasiado costosa la inversión y el mantenimiento y pocos los beneficios que deja al Estado. Y aunque opta, en un principio, por la gestión directa de todos los establecimientos, en poco tiempo los cede en arrendamiento a gestores con experiencia ${ }^{20}$.

Los capítulos de información, propaganda y publicaciones, cuya gestión anterior fue ampliamente criticada por su abultado coste, buscan racionalizar la inversión y disminuir los gastos. Entre otras cosas, se reducen las agencias de viajes en el exterior, conservando como tales sólo las de París, Roma, Gibraltar y Buenos Aires, se reutilizan los fondos editoriales sin distribuir del anterior Patronato, añadiendo a la portada «Gobierno de la República» y se firma un contrato con la editorial Calpe para publicar cincuenta guías de España, una por cada provincia, en vez de hacerlo el propio Patronato.

Las relaciones del Patronato con Cataluña mejoran con el establecimiento de la Generalitat, a la que transfiere la representación y cede en usufructo sus seis oficinas en la región, corriendo los gastos de organización, propaganda e información por cuenta del nuevo organismo. La Generalitat, que aspira a tener a su cargo todas las competencias turísticas, implanta en 1932 la Oficina de Turismo de Cataluña, pero un año después, el Estado crea el Patronato de Turismo de Cataluña, con carácter

\footnotetext{
${ }^{19}$ La Junta, presidida por el subsecretario de la Presidencia del Consejo de Ministros, está formada por el secretario del Patronato, un vicepresidente (el director general de Bellas Artes), seis vocales (cuatro por los ministerios de Marina, Hacienda, Fomento y Economía) y dos del mundo académico procedentes de la Facultad de Filosofía y Letras y del Centro de Estudios Históricos, y un vicesecretario.

${ }^{20}$ Se inauguran en 1931 los dos paradores que se estaban ejecutando en antiguos conventos: el de Ciudad Rodrigo (Salamanca) y el de Mérida (Badajoz). También se construyen la mayoría de los albergues previstos con anterioridad y el resto, algunos con el carácter de paradores, lo harán durante el franquismo.
}

consultivo y asesor de la Generalitat en todo lo referido a la organización y servicios de turismo, a la que se adscribe la Oficina de Turismo. Ambos patronatos se encargarán de desarrollar la articulación y las pautas de acción, contando con la colaboración de los colectivos locales a los que reconoce como verdaderos impulsores del turismo (Montaner, 1997).

\section{LAS INICIATIVAS COLECTIVAS LOCALES PARA EL FOMENTO DEL TURISMO}

El Gobierno central siempre vio con recelo las iniciativas colectivas de fomento del turismo, denominadas Sociedades de Atracción de Forasteros o Sindicatos de Iniciativas Turísticas. La repetida queja de estos colectivos es la falta de atención por parte de los organismos públicos a sus demandas de dinero e infraestructuras necesarias para impulsar el turismo de sus territorios.

Estas organizaciones de carácter local, provincial o regional se constituyen en su mayoría a principio del siglo xx e imitan a las de Suiza, Francia e Italia. Las componen personalidades relevantes de la vida empresarial y política, profesiones liberales e, incluso, las apoyan las administraciones locales. Persiguen facilitar la comodidad y el confort de los visitantes extranjeros y nacionales y difundir los valores naturales y el patrimonio cultural de sus territorios. La primera surge en Málaga en 1897 y le sigue la de San Sebastián. En el periodo de la Comisión Nacional se crean en Palma de Mallorca, Barcelona, Tarragona, Burgos, Cádiz, Madrid y Bilbao y con la Comisaría Regia, en Menorca, Salamanca, Santa Cruz de Tenerife, Valencia, Pamplona, Aragón y Madrid. En tiempos del Patronato monárquico se fundan en La Garriga y en Madrid y ya en la República, en Gran Canaria ${ }^{21}$.

La pionera es la Sociedad Propagandista del Clima y Embellecimiento de la ciudad de Málaga, creada en 1897 con la intención de aunar en un proyecto común diferentes iniciativas para organizar de manera racional y programada la explotación del turismo en la ciudad. Un artículo en El Avisador Malagueño de 1872 insiste en el estado de conciencia latente en la sociedad malagueña de las grandes posibilidades que ofrece el clima de la ciudad para atraer turistas. Los estudios médicos Del clima de Málaga y Medios prácticos de convertir a Málaga en

\footnotetext{
${ }^{21}$ La relación de organizaciones podría ser más larga. Aquí sólo aparecen las mencionadas en los estudios referenciados en la bibliografía y las halladas en otros medios a lo largo de la investigación.
} 
la mejor estación de invierno de Europa, publicados en 1880 , recogen opiniones de especialistas extranjeros que asignan a la ciudad el primer lugar entre las estaciones médicas de la Península y recomiendan a las autoridades y a los capitalistas malagueños afrontar la tarea de convertir la ciudad en una estación de invierno (Torres, 1983). En la misma línea se decanta el folleto de 1894 Málaga estación de invierno. Por y para ella, que revela la vinculación entre estas iniciativas y un cierto espíritu regeneracionista (León, 1894).

Constituyen la organización destacados miembros de la sociedad malagueña, empresarios, senadores, diputados y un importante núcleo de extranjeros franceses y británicos residentes, jugando los cónsules un papel relevante, especialmente el de Inglaterra, que será su principal promotor. La financiación la obtiene de la burguesía malagueña y de entidades privadas y públicas, entre ellas la Compañía de Tranvías, la Casa Larios, la Sociedad Filarmónica o la Diputación Provincial. Las actividades se publican en el periódico La Unión Mercantil y se orientan a la propaganda del clima, para lo que emprende un amplio plan de instalación de observatorios, cuyos resultados se envían regularmente a las principales capitales europeas y revistas médicas inglesas. También se preocupa del embellecimiento urbanístico y la higiene pública, para lo que promueve diversas obras de ensanche, pavimentación y embellecimiento de calles, plantación de árboles y colocación de fuentes públicas y, finalmente, a los festejos y actividades culturales (Arcas y Cubero, 1980).

El Centro de Atracción y Turismo de San Sebastián se constituye en 1903 a la sombra del Casino, que funcionaba desde 1887. Consigue subvenciones del Ayuntamiento y en 1909 organiza el Segundo Congreso Internacional de Turismo. La Sociedad para el Fomento del Turismo de Palma de Mallorca de 1905 tiene entre sus primeros impulsores al archiduque Luis Salvador de Austria y a ella se adhieren varios grupos de excursionismo. Trabaja en promover las infraestructuras necesarias para facilitar todo género de excursiones, en especial por la sierra de la Tramontana, para lo que acondiciona y señaliza caminos y senderos, incorpora elementos de seguridad y defensa en puntos peligrosos, introduce postes indicadores, traza caminos de montaña y construye miradores y refugios. También publica folletos y guías en varios idiomas (<www.fomentmallorca.org $>$ ).

A partir de la herencia que deja la Exposición Universal de Barcelona de 1888, un grupo de personalidades relevantes de la vida empresarial y política catalana y barcelonesa, con el apoyo del Ayuntamiento, crea en
1908 la Sociedad de Atracción de Forasteros de Barcelona. Los impulsores, cercanos a la Liga Regionalista, creen que el turismo puede modernizar Cataluña además de enriquecerla cultural y económicamente. La Sociedad es una especie de agencia catalana de turismo con una extensa red de delegados en España y el extranjero. Su fin es «puramente patriótico y desinteresado», centrado en la promoción del turismo en Barcelona y, por extensión, a toda Cataluña. Publica un boletín mensual con el nombre de Touring Review, convertido en 1912 en la revista trimestral Barcelona Atracción, como medio de comunicación y propaganda de la institución en España, Europa y América, y que reparte gratuitamente entre los socios, hoteles, compañías navieras y ferroviarias, agencias de viaje, prensa de información general y turismo o sociedades deportivas. Publicita a Barcelona en 1914, como ciudad que contiene en ella misma tres tipos de ciudad: la americana, por sus negocios y congresos; la francesa, como ciudad de placer en invierno, y la italiana, como memoria cultural (Blasco, 2005). Los recursos provienen de las cuotas de sus socios, de la publicidad que se inserta en la revista y de las subvenciones que reciben de los ayuntamientos y diputaciones, mancomunidad de Cataluña y, más tarde, de la Generalitat. Edita carteles, guías y postales. Sus actividades son muchas, entre otras, organiza el Primer Congreso Nacional de Turismo en 1919²2; consigue la escala de cruceros de turismo, y produce la película Barcelona, perla del Mediterráneo en 1911 para promover el turismo de la ciudad. La Sociedad presenta sin éxito a la Comisaría el proyecto de un itinerario turístico en automóvil por gran parte del país, que también apoyaban el Real Automóvil Club y el Centro Excursionista de Cataluña.

El estado de opinión crítica sobre la actuación de la Comisaría Nacional bien puede ser la espita que propicia la creación en 1910 de varios sindicatos de iniciativas. El de Bilbao surge de la mano de un grupo de personalidades de la vida social, económica y política que quieren hacer de la ciudad algo más que un centro rector del sector industrial y financiero, esto es, un centro turístico ( $E l$ Correo, 2010). El de Tarragona se funda con el propósito de promover y divulgar el legado romano y medieval de la provincia, y organiza el Segundo Congreso Nacional de Turismo en 1921. No obstante, Tarragona ya contaba

\footnotetext{
${ }^{22}$ La lengua oficial del congreso es la catalana y los trabajos presentados se centran en la organización y funcionamiento de los sindicatos de iniciativas, propaganda y publicidad, servicios públicos y comunicaciones, excursionismo, monumentos y bellezas naturales, hoteles, balnearios y estaciones de invierno y verano (Montaner, 1998)
} 
con una larga tradición en la recepción de visitantes en la ciudad y sus alrededores, en especial, a los monasterios cistercienses de Poblet y Santes Creus, desplazándose ya en 1882 la sociedad de excursionismo cultural Lo Rat Penat desde Valencia a Tarragona (Ortuela, 2007).

En Burgos se crea la Asociación Nacional de Fomento de Turismo, tutelada por Alfonso XIII y liderada por el Ayuntamiento. Participan la Diputación, la Cámara de Comercio, la Comisión de Monumentos, la prensa local, los hoteles, cafés y casinos, la Iglesia, los Ferrocarriles del Norte y la Delegación del Ministerio de Obras Públicas. Solicita al Estado la reparación de las carreteras y consigue la instalación de señales informativas en los principales cruces (Diario de Burgos, 2013). En Madrid, auspiciada por el marqués de Marianao, surge la Asociación de Propaganda de Madrid Fomento del Turismo, declarada corporación oficial en 1911 cuando la preside el ex alcalde conde de Peñalver. Organiza en 1912 el Quinto Congreso Internacional de Turismo e insiste en impulsar lo artístico y cultural en la promoción del turismo (González, 2005). La Sociedad de Turismo de Cádiz, aunque se constituye en 1910 por un grupo de emprendedores locales y apellidos importantes de la vida gaditana, a los dos años ya cuenta con una serie de cargos honoríficos (el propio comisario regio, el gobernador civil, el comandante de Marina, el alcalde de la ciudad y el director de las obras del puerto) y de personajes de peso entre los que destaca el marqués de Comillas, que aportan cuantiosos fondos. La Sociedad aspira a hacer de la ciudad el ombligo de Europa y América. En su quehacer diario facilita al visitante información sobre itinerarios, excursiones, transporte y hospedaje, y le obsequia con la Guía del turista en Cádiz (Marchena, 1998).

Ya en tiempos de la Comisaría se crea en 1919 en el marco levantino la Sociedad Valenciana para el Fomento del Turismo. Edita para su promoción la revista Valencia Atracción, que da a conocer los lugares, edificios notables, obras de arte y fiestas de la ciudad y de la región. Impulsa activamente la fiesta de las Fallas, al organizar el primer tren fallero desde Madrid y el barco fallero desde América del Sur. Consigue para la fiesta un gran apoyo popular y también de la prensa reflejado en la publicación de un sinfín de revistas locales: El Turista Fallero, Pensat y Fet, El Cuhet, El Bunyol, Senyera, Nit de Foc, Les Flames (Puche y Obiol, 2011). En Zaragoza, tras el Primer Congreso Internacional de Turismo de 1908 surge el germen de lo que será el Sindicato de Iniciativas y Propaganda de Aragón, fundado en 1925. Se autodefine como una obra patriótica y desinteresada que adopta el lema «Por y para Aragón». Formado por sectores profesionales y empresariales, se dedica a la defensa, conservación y difusión del patrimonio histórico-artístico de la región (SIPA).

La Sociedad de Atracción de Forasteros de Madrid se crea en 1926 y edita ese mismo año la revista Turismo como órgano de difusión y con subvención del Ayuntamiento. En 1928 la revista se reemplaza por Viajes por España, dirigida por el presidente de la Cámara Oficial de Comercio de Madrid, que cuenta con el apoyo de destacados miembros de la política nacional y es la única que cuenta con subvención del Patronato Nacional de Turismo. La revista se ofrece a las sociedades de iniciativas para dar a conocer a través de ella sus respectivas regiones y así, señala, «llegaremos a dar verdaderos itinerarios para efectuar viajes de placer y recreo por todos los rincones de nuestra amada patria, para que con ello quede bien demostrado que, sin salir de España, puede gozarse de todos cuantos encantos nos brindan los viajes por lejanas tierras». Sin embargo, en la publicación sobresalen los reclamos turísticos de la ciudad y lugares del entorno (sierra de Guadarrama, El Escorial o El Paular), pocos de Castilla y Andalucía y nada del resto, salvo Vigo, desde donde proyecta una autovía hacia Madrid (Viajes por España, 1928).

En tiempos del Patronato, en la pequeña localidad del interior catalán de La Garriga se funda en 1929 la Sociedad de Atracción de Forasteros, donde la frecuentación de visitantes a las instalaciones balnearias de aguas minerales se hace cada vez más evidente. Edita folletos, organiza excursiones y festivales, restaura algunas fuentes y pide insistentemente a la Administración la limpieza y pintura de las fachadas de la localidad, mayor iluminación y la creación de parques y jardines (Molina, 2004). Y en Madrid se constituye en 1934 un Sindicato de Iniciativas y Turismo con la intención de dar a conocer los monumentos, rincones típicos, costumbres y paisajes de Madrid y su entorno. Se queja de la escasa consideración de los Gobiernos españoles por los sindicatos de iniciativas, que no han recibido apoyo económico ni tampoco un puesto en la organización turística oficial. El Sindicato publica un boletín semanal que se sirve gratuitamente a todos los asociados y entidades similares donde publica noticias de actualidad referentes a Madrid y al turismo. También edita desde 1935 la revista Madrid Turístico y Monumental con artículos sobre los recursos de la ciudad y sobre la sierra de Guadarrama. Asimismo da noticias de los paradores, albergues y hosterías del Patronato, y de los hoteles, pensiones y restaurantes de Madrid adheridos al Sindicato. En 1935 cuenta con 47 corresponsales 
distribuidos por toda España (Madrid Turístico y Monumental, 1935 y 1936).

Las reuniones y asambleas de los sindicatos de iniciativas culminan en la creación de la Federació de Turisme de Catalunya en 1932 y un año después la Federación Española de Sindicatos de Iniciativas y Turismo, en la que se integra la catalana. La federación nacional opera en un espacio triangular apoyado en San Sebastián, Palma de Mallorca y Valencia, con un vértice apuntando a Madrid, sin penetración en Andalucía y con escasa operatividad en Cataluña, región que cubre la Federación. Consiguen que en 1935 el Gobierno decrete la representación de los sindicatos en la Junta Consultiva del Patronato Nacional de Turismo y declare «asociación de utilidad pública» a la Federación Española y a cada uno de los sindicatos que la integran $(A b c, 1935)$.

\section{LA OFERTA Y PROMOCIÓN DEL TURISMO DEL SECTOR PRIVADO}

En el primer tercio del siglo xx el sector privado sigue interesado por los enclaves turísticos tradicionales. El negocio balneario de aguas minerales se centra ahora en los establecimientos de reconocida fama que ahora se modernizan, incorporan nuevas actividades de ocio o amplían su actividad con la explotación industrial de las propiedades de las aguas. Y algunos vivirán su mejor época ${ }^{23}$. Para proteger y fomentar los intereses de la industria balnearia catalana se crea en 1916 la Asociación de Dueños de Balnearios y Manantiales Minero-Medicinales de Cataluña, con vínculos muy directos y estrecha relación con la Sociedad de Atracción de Forasteros de Barcelona.

La oferta turística en los enclaves de baños de playa de mayor éxito sale del recinto balneario, se propaga por la ciudad y ésta se acondiciona para recibirla. San Sebastián en vísperas de la República sigue siendo el mayor centro de ocio de España, digna rival de los más importantes de Europa, cuando la ciudad se ha convertido en una combinación de playa, lugar de entretenimiento, centro de compras de la alta sociedad y punto de partida de cortas excursiones por los alrededores. Las posibilidades

\footnotetext{
${ }^{23}$ El cántabro balneario de Coronte alcanza su apogeo a partir de 1922 cuando introduce nuevas diversiones para los clientes: tenis, croquet, bolera montañesa, alquiler de caballos, tiro al plato y al blanco, baile, conciertos, cinematógrafo, e incorpora una planta embotelladora (Martínez, 1997). El de Panticosa se moderniza en 1919 al tomar el negocio la empresa Energía e Industrias Aragonesas, S. A. (Monserrat, 1995). El de Toxa instala una fábrica de sales de baño, jabón y otros productos cosméticos que exporta al mercado americano y británico (Vilar, 2011)
}

de la costa mediterránea catalana interesa a empresarios y agentes inmobiliarios, que ponen en circulación los terrenos aún vírgenes para convertirlos en colonias residenciales de vacaciones destinados a la alta burguesía barcelonesa, como la de Terramar en Sitges $^{24}$ y otras similares en Vilanova i la Geltrú, Calafell y Vendrell (Molina, 2004). El nombre de «Costa Brava», atribuido al escritor F. Agulló desde 1908, se utiliza para promover el turismo del conjunto de poblaciones desde Blanes hasta la frontera francesa y la Conselleria d'Obres Públiques de la Generalitat mejora de los accesos a las calas, facilitando el éxito de Tossa de Mar y S'Agaró, aquí con el lujoso Hostal de la Gavina de 1932, que marca el comienzo de un turismo de élite internacional (Moreno, 2007). La localidad gaditana de Sanlúcar sigue destacando en el panorama andaluz por su amplia oferta turística de playa y actividades recreativas durante el verano ${ }^{25}$. En la isla de Mallorca el turismo se concentra a finales de los años veinte en las bahías de Palma, Alcúdia y Pollença, y en los treinta aparecen las primeras urbanizaciones promovidas por industriales locales e inversionistas europeos en Palma, Cala d'Or y Alcúdia, localidad donde se construye el primer club de golf de España en 1934. La playa valenciana de la Malvarrosa, las alicantinas de Postiguet y Santa Pola, y la murciana de los Alcázares empiezan a ser frecuentadas desde los años veinte. Y en el Mediterráneo andaluz, con la llegada del primer crucero turístico en 1930 a Málaga se potencian las playas de la ciudad, Pedralejo y Valle de los Galanes.

La afición por el excursionismo se incrementa, apoyada por la mejora de las infraestructuras y la construcción de senderos. Aparecen nuevas sociedades que promocionan el turismo deportivo, especialmente de montaña. Así, cabe citar la creación del Twenty Club en 1906, convertido en el Club Alpino Español dos años después; la Secció d'Esport de Muntanya en 1908, surgida en el seno del Centre Excursionista de Catalunya; la Sociedad Gredos-Tormes de Hoyos del Espino en 1911,

\footnotetext{
${ }^{24}$ Como parte de la colonia se construye la estructura lacustre del Pabellón del Mar, el casino Platja d'Or y el hotel Terramar, propiedad de la sociedad Terramar Parques y Edificaciones, S. A. Completa los equipamientos un gran autódromo, promovido por una sociedad por acciones, situado en la contigua población de San Pere de Ribes (Tatjer, 2009)

${ }^{25}$ En una guía local de 1912 se ofrecen cines, teatros, corridas de toros, carreras de caballos, ferias y fiestas, procesiones y romerías, paseos a orillas del mar y por la alameda, con sus veladas musicales e iluminación espléndida. Resalta la afluencia y animación de viajeros, y el movimiento constante de automóviles que aumenta cada año y hacen de la ciudad el primer punto de veraneo de toda Andalucía (Valero, 1991). La localidad vive en los años treinta un gran desarrollo veraniego por la atracción de sus cuatro casinos, tres teatros, restaurantes, nuevos hoteles, e instalaciones para baños en la playa.
} 
para promover el turismo en la provincia de Ávila y sur de la sierra de Gredos; la Real Sociedad de Alpinismo Peñalara en 1912, muy vinculada a los círculos institucionistas y que edita la revista Peñalara, o la Sociedad Deportiva Excursionista en 1913, para fomentar el acercamiento de las capas populares a la sierra madrileña.

Las agencias de viajes juegan un papel importante en estos años para atraer turistas. Entablan relaciones con las compañías trasatlánticas o de ferrocarriles, con los hoteles y con agencias de viajes europeas para recepcionar a los viajeros. La agencia española más importante nace en 1910, en Barcelona, como una sección de la banca Marsansrof, convirtiéndose en 1920 en la Agencia Marsans, S. A., y tiene en 1936 ocho oficinas y once delegaciones en España. Se inicia organizando viajes a París y Suiza, y pronto recibe viajeros de América y Europa que llegan con pasajes expedidos por las navieras extranjeras o compañías internacionales de ferrocarriles; promueve en 1928 el Primer Congreso de la Federación Internacional de Agencias de Viajes, donde se reúnen treinta agencias de toda Europa; atrae turistas de Estados Unidos al obtener la representación de American Express en España (Expansión, 2010). Otras agencias de viajes catalanas nacen al filo de la Exposición de 1898 y organizan excursiones a la Costa Brava, Monserrat, Pirineo aragonés, Andalucía y Francia. Por su parte, la Comisaría Regia deniega la petición de algunas agencias de viajes de convertirse en compañías oficiales. Lo solicita en 1914 la Compañía de Turismo Hispano-Americano, que encauza turistas desde el continente americano. Tampoco lo consigue en 1926 la empresa Hijos de M. Condeminas, puntera en el sector turístico catalán ${ }^{26}$.

Antes de la guerra civil, casi todas las navieras internacionales hacen escala en los principales puertos mediterráneos. A la bonanza de los cruceros deben su origen agencias dedicadas a ofrecer excursiones por el interior, como la Bakumar de Málaga o la Sociedad Anónima de Iniciativas Turísticas de Vigo. En la isla de Mallorca se visitan las cuevas de Drac y Artà, la sierra Tramontana y la cartuja de Valldemosa, en una interesante oferta de turismo natural y cultural. Y desde 1930 la Compañía Transmediterránea ayuda a consolidar la demanda nacio-

\footnotetext{
${ }^{26}$ La empresa trabaja con compañías de navegación extranjeras y es agente de las compañías de servicios aéreos españoles; tiene oficinas propias en Madrid, Barcelona, Sevilla y Palma de Mallorca, y agencias en muchas otras ciudades; dispone de automóviles y autocares para excursiones y de intérpretes uniformados en las fronteras. En 1914 pide apoyo oficial y subvenciones para encauzar la propaganda y establecer en París una oficina ante la inminente creación de un Ministerio de Turismo (Correyero y Cal, 2008).
}

nal con viajes semanales a las tres islas Baleares desde Valencia, Tarragona, Alicante y Barcelona, y también ofrece excursiones a la Costa Brava.

El sector hotelero sigue interesado en el turismo urbano. Tras la Asamblea Nacional de Fondista se crea en 1908 la Asociación de Fondistas y Similares de España que hará una interesante labor de fomento y propaganda al editar pequeñas guías y publicaciones periódicas. Por su parte, a propuesta de la Federació y de la Associació d'Hotelers i Similars de Catalunya se celebra en 1934 el Primer Salón de Turismo y los Deportes aprovechando la VII Feria de Barcelona, donde pide, entre otras cosas, la declaración de parques nacionales para determinados enclaves de Cataluña (Blasco i Peris, 2005). Y también empresas extranjeras se interesan pronto por el negocio hotelero. La Sociedad Franco-Española de Grandes Hoteles y Viajes en España y Portugal, S. A. funciona desde 1905 como entidad hotelera y agencia de viajes, y administra hoteles en Madrid, Alicante y Málaga. Ya en los años veinte las más importantes ciudades españolas cuentan con hoteles de lujo de empresas multinacionales, como la cadena Les Grands Hotels Européens de los Marquet, que centra en 1927 sus operaciones en hoteles en Madrid, Santander y Sevilla.

También las editoriales se lanzan a promocionar el turismo de ciudades y territorios con la edición de guías. En 1923 Espasa-Calpe saca la Guía de Levante a cargo de Elías Tormo, la primera de la colección España. Guías Regionales, que dirige Dantín Cereceda. La promoción del turismo en las islas Canarias también viene de la mano de la edición de libros y guías. En 1932 se publica en Berlín la obra Madeira Canarische Inseln und Azoren, con diez mapas a color de cada una de las islas y tres planos, incorporando el de Tenerife los caminos, las carreteras y las vías conectadas por líneas de autobuses; en 1933 y a iniciativa de la Junta Provincial de Turismo se edita la Guía pintoresca: Gran Canaria, en español, francés, inglés y alemán; y el folleto Gran Canaria: continente en miniatura, con 29 fotografías de afamados fotógrafos de la época y un mapa con la localización de la isla en el Atlántico e indicación de las rutas de conexión marítima (Domínguez, 2007).

Surgen revistas como Turismo Ibérico, especializada en estaciones balnearias; la Brittish Colony Gazette, que edita desde 1926 la colonia inglesa residente en Málaga, difundiendo por Gran Bretaña, Estados Unidos y Suramérica los recursos turísticos de la ciudad y su entorno; o El Turismo en Málaga, que en 1929 se distribuye en España, Europa y América. Y aparecen periódicos especializados en turismo, como el pionero barcelonés $E l$ 
Viajero; El Pregón, que ya en 1927 introduce una sección titulada «Los bellos lugares del turismo malagueño»; o la página semanal en inglés titulada Today Weekly English News, que incorpora La Unión Mercantil de Málaga desde 1931 (García, 2004).

En 1932 se edita la primera publicación ilustrada de turismo de carácter nacional, la Revista Española de Turismo (RET), de la Editorial Turística Ibérica. Aparece como órgano periodístico desligado de todo interés industrial para la difusión, dentro y fuera de España, de la riqueza turística nacional, de sus recursos naturales, artísticos y monumentales. Cada número contiene textos acompañados de abundantes fotografías, y desde 1933 los sumarios aparecen en español, alemán, francés e inglés. Quiere ser un lazo de unión entre los amantes del excursionismo y del turismo, y busca crear grupos de entusiastas en todas las poblaciones. En sus páginas informa de playas para el veraneo e indica su accesibilidad y servicios de alojamiento y ocio; incluye reportajes sobre espacios naturales y ciudades singulares de toda España; fomenta un viaje en automóvil desde París que bautiza «Del corazón de Europa al corazón de Marruecos pasando por España», con itinerarios y kilometraje, lugares a visitar, alojamientos y excursiones (Revista Española de Turismo, 1932 y 1933).

\section{CONCLUSIONES}

En los escenarios turísticos que se reconocen en la geografía española se observan distintos comportamientos en los agentes implicados en su oferta y promoción. Las actuaciones del sector privado se decantan por el negocio de una oferta de consumo de enclaves de naturaleza, los balnearios, cuya naturaleza domestica, o de paisajes costeros que urbaniza, o bien de alojamientos y ocio en los núcleos urbanos de mayor demanda. Los círculos excursionistas, por su parte, divulgan y fomentan el uso de paisajes naturales, especialmente de montaña, entre la sociedad urbana. Finalmente, los colectivos locales, en su afán por dinamizar sus economías, promocionan sus ciudades o territorios y fomentan el uso de sus recursos naturales y culturales, a través de una imagen turística que los singulariza en el panorama nacional.

La actuación del sector público se centra en facilitar la entrada y la comodidad de la estancia al turista extranjero y en divulgar los recursos culturales, especialmente los de la España interior, sin apenas dar entrada a los nuevos referentes turísticos al gusto de la sociedad europea emergente. Al mismo tiempo, difunde una ima- gen turística del país como una unidad centralista, donde se descarta la diversidad regional, salvo en lo folclórico y pintoresco. En este sentido, merecen destacarse las iniciativas y actuaciones que surgen en Cataluña, por su espíritu europeísta y que, salvo en tiempos de la República, en poco serán consideradas ni reconocidas por la administración turística.

\section{BIBLIOGRAFÍA}

$A b c$ (17-11-1935).

Alonso Álvarez, L. (2011): «El agua como ventaja. Orígenes y expansión del turismo termal en España, 1750-2010», en X Congreso Internacional de la AEHE, $<$ www.aehe.net/xcongreso $>$.

Arcas Cubero, F., y A. García SÁnchez (1980): «Los orígenes del turismo malagueño: la sociedad propagandista del clima y embellecimiento de Málaga». Revista Jábega, núm. 32, <www.cedma.com>.

Blasco i Peris, A. (2005): Barcelona Atracción (19081936). Una revista de la Sociedad de Atracción de Forasteros de Barcelona. Tesis doctoral, Universitat Pompeu Fabra, Barcelona, <www.sibhilla.uab.cat/ cgi-bin>.

Boletín de la Sociedad Española de Excursiones, (18931954). <www.ddd.uab.es/record/40577>.

Cabanes, A., y R. GonzÁlez (2009): «El ferrocarril como pieza clave en los inicios del turismo en España (1905-1960): fuentes documentales para su estudio», en $V$ Congreso de Historia Ferroviaria. <www.docutren.com/congreso_palma>.

CAL, R. (1997): «La propaganda del turismo en España. Primeras organizaciones». Historia y Comunicación Social, 2, <www.revistas.ucm.es>.

Carulla, J. (1994): España en 1.000 carteles. Postermil, Barcelona.

- y A. Carulla (1998): La publicidad en 2.000 carteles. 2 vols., Postermil, Barcelona.

Caz, R., y M. Saravia (1994). «De las entrañas de la tierra. Contribución al estudio de los balnearios decimonónicos». Historia Urbana, núm. 3, pp. 39-60.

Correyero, B., y R. CAL (2008): Turismo: la mayor propaganda de Estado. España: desde sus inicios hasta 1951. Visión Libros, Madrid.

Diario de Burgos, 13-12-2013, <www.diariodeburgos.es>. Domínguez MúsICA, J. (2007): «La cartografía en la promoción turística de Canarias (1880-1970)». Boletín de la AGE, núm. 44, pp. 279-300.

El Correo de Álava, 22-8-2010, <www.elcorreo.com>. 
Estévez Monzó, E. (2002): «Noticias y publicidad en los comienzos del turismo en Canarias: el Diario de Tenerife de 1887». Revista Latina de Comunicación Social, núm. 46, <www.ull.es/publicaciones/latina>.

Expansión (2010), <www.expansion.com>.

Foment del Turisme de Mallorca, <www.fomentmallorca.org $>$.

Garay Tamajón, L. A., y G. Cànoves Valiente (2009): «El desarrollo turístico en Cataluña en los dos últimos siglos: una perspectiva transversal», Doc. Anàl. Geogr., núm. 53, pp. 29-46

García Galindo, J. A. (2004): «Prensa y turismo en España (Málaga, 1872-1936)». Centros y Periferias (Universidad de Málaga), pp. 169-178.

Gil DE ARribA, C. (2000): «La difusión social y espacial del modelo balneario: de la innovación médica al desarrollo de las prácticas de ocio». Scripta Nova, núm. 69 (40), <www.ub.edu/geocrit/nova>.

González Morales, J. C. (2005): «La Comisión Nacional de Turismo y las primeras iniciativas para el fomento del turismo: la industria de los forasteros (1905-1911)». Instituto de Estudios Turísticos, núm. 163-164, pp. 17-30.

Gómez de Bedoya, P. (1764): Historia universal de las fuentes y baños minerales de España, <www.books. google.es/book/about/Historia_universal_de_las_ fuentes_minera>.

Guía del bañista en el Molar (Fuente del Toro) (1897), $<$ www.bibliotecavirtual/madrid.org $>$.

Guía ilustrada de las aguas mineromedicinales y balnearios de España (1896). Imprenta Colonial, Madrid.

Instituto DE Estudios Turísticos (2005): Catálogo de carteles oficiales de turismo, 1929-1959. Instituto de Estudios Turísticos, Madrid.

- <www.iet.tourspain.es/documentacionturistica $>$.

Jaimez Gago, I. (2004): Políticas públicas y turismo. Junta de Andalucía, Sevilla.

JARRASÉ, D. (2002): «La importancia del termalismo en el nacimiento y desarrollo del turismo en Europa en el siglo XIX». Historia Contemporánea, núm. 25, pp. 33-49.

Jiménez, S., y L. Prats (2006): «El turismo en Cataluña: evolución histórica y retos de futuro». Pasos, vol. 4, núm. 2, pp. 153-174.

La Voz de Galicia (16-2-2011), <www.lavozdegalicia.es>.

LARrinAGA, C. (2002): «El turismo en la España del siglo XIX». Historia Contemporánea, núm. 25, pp. 157-179.

- (2010): «Dos balnearios atlánticos entre el fin de siglo y la crisis del treinta, San Sebastián y Mar del Plata. Un ejercicio comparativo». Historia Contemporánea, núm. 38, pp. 277-310.
- (2011): «Derechos de propiedad y capitalismo termal en el siglo XIX en Guipúzcoa», en X Congreso Internacional de la AEHE. Sevilla, <www.aehe.net/xcongreso>.

LAVAUR, L. (1977): «Albores del turismo moderno (18501879)». Estudios Turísticos, núm. 53-54, pp. 9-40.

LEÓN, L. DE (1894): Málaga, estación de invierno, $<$ www.bibliotecavirtualdeandalucia.es $>$.

Madrazo, S. (1991): «Localización de balnearios en 1867». Ciudad y Territorio, núm. 89, pp. 230-231.

Madrid Turístico y Monumental (1935 y 1936), <www. hemerotecadigital.bne.es $>$.

Marchena Domínguez, J. (1998): «La Sociedad de Turismo de Cádiz (1910): una alternativa al resurgimiento de la ciudad», en Estudios de la Universidad de Cádiz ofrecidos a la memoria del profesor Braulio Juste Calabozo. Cádiz, pp. 519-524.

Martín EMPARÁn, A. (2008): El diseño gráfico en la Exposición Iberoamericana de Sevilla (1929). Tesis doctoral, <www.biblioteca.uma.es/bbldoc/tesisuma $>$.

Martínez Ruiz, E. (1997): «Balnearios y aguas termales en Campoo». Cuadernos de Campoo, núm. 10, $<$ www.vacarizu.es/Cuadernos $>$.

Molina Villar, J. J. (2004): Termalismo y turismo en Catalunya: un estudio geohistórico contemporáneo. Tesis doctoral, Universidad de Barcelona, <www.tdx. cat/handle/10803/1942>.

Monserrat Zapater, O. (1995): «Un espacio de salud y ocio en el Pirineo aragonés: el balneario de Panticosa». Ería, núm. 36, pp. 35-53.

Montaner i Montejano, J. (1997): «El turisme durant la Generalitat republicana». Estudis de Turisme de $\mathrm{Ca}$ talunya, núm. 1, <www.gencat.es/turismo>.

- (1998): «La Societat d’Atracció de Forasters de Barcelona (1908-1936)». Estudis de Turisme de Catalunya, núm. 3, <www.gencat.es/turismo>.

- (2004): «Cent anys de cartells turístic a Catalunya». Estudis de Turisme de Catalunya, núm. 15, <www. gencat.es/turismo $>$.

Moreno Garrido, A. (2004): Turismo y nación. La definición de la identidad nacional a través de los símbolos turísticos. España 1908-1929. Tesis doctoral inédita.

- (2005): «Turismo de élite y administración turística de la época (1911-1936)». Estudios Turísticos, 163164, pp. 31-54.

- (2007): Historia del turismo. Síntesis, Madrid.

- (2010): «El Patronato Nacional de Turismo (19281932). Balance económico de una política turística». Investigaciones de Historia Económica, pp.103-134

- (2011): «La estrategia atlántica. Élites económicas e intereses turísticos en la España de Primo de Rivera». 
Historia Económica, núm. 41, <www.historiacontemporanea.ehu.es $>$.

Ortega CAntero, N. (2013): «Paisaje, patrimonio e identidad en la conformación de la primera política turística española». Ería, en prensa.

Ortuela Hilberath, E. de (2007): «Tarragona destino turístico. El Patronato Cultural y los nuevos espacios para el ocio». Norba-Arte, vol. XXVII, pp. 263-284.

Pellejero, C. (2002): «La actuación del Estado en materia turística durante la dictadura de Primo de Rivera». Revista de Historia Económica, núm. 1, pp. 149-158.

Puche, M., у E. Овіо (2011): «Procesos de re-imageneering turístico: el eclipse de la identidad local de Valencia». Cuadernos de Turismo, núm. 28, pp. 191-214.

Revista Española de Turismo (1932 y 1933), <www.hemerotecadigital.bne.es $>$.

ROCA RICART, R. (2011): La Renaixença valenciana y el redescubrimiento del país. El Centro Excursionista de Lo Rat Penat (1880-1911). Denes, Valencia.

Rodríguez Bernal, E. (1994): Historia de la Exposición Iberoamericana de Sevilla de 1929. Ayuntamiento de Sevilla, Sevilla.

Rubio, P. M. (1853): Tratado completo de las fuentes minerales de España. Madrid, <www.books.google.
es/.../Tratado_completo_de_las_fuentes_minerale. html>.

Sánchez Cantón, F. J. (1925): España. Publicaciones de la Comisaría Regia de Turismo, Madrid.

SIPA, CENTRO DE INICIATIVAS TuRÍstiCAS, <www.siparagon. es>.

TATJER, M. (2009): «En los orígenes del turismo litoral: Los baños de mar y los balnearios marítimos en Cataluña». Scripta Nova, vol. XIII, núm. 294 (5), <www. ub.edu/geocrit/nova>.

Torres Bernier, E. (1983): «Los orígenes del turismo andaluz». Estudios Regionales, núm. 12, pp. 331-365.

VALERO, A. (1991): «El turismo en España entre 1850 y 1950. Creación, madurez y crisis», en A. García Lorca y F. Fourneau (coords.): Desarrollo regional y crisis del turismo en Andalucía. Instituto de Estudios Almerienses/Casa de Velázquez, Almería, pp. 297-326.

Viajes por España (1928-1929), <www.hemerotecadigital.bne.es>.

Vilar RodríGuez, M. (2011): «Balnearios, intereses políticos y desarrollo turístico en el noroeste de España: el caso de A Toxa y Mondariz (1874-1935)». Cuadernos de Historia Contemporánea, vol. 33, pp. 163-185. 